UDK 329.12:327

Biblid 0543-3657, 71 (2020)

God. LXXI, br. 1179-80, str. 5-22

izvorni naučni rad

Primljen: 25.8.2020.

doi: https://doi.org/10.18485/iipe_mp.2020.71.1179_80.1

Žaklina NOVIČIĆ ${ }^{1}$

Isidora POP-LAZIĆ

\title{
Sinoptički neorealizam: osvrt na Minhensku školu i konstelacionu analizu međunarodnih odnosa
}

\section{SAŽETAK}

Tekst predstavlja osvrt na sinoptički neorealizam i konstelacionu analizu međunarodnih odnosa, koju je krajem sedamdesetih godina prošlog veka zasnovao Godfrid-Karl Kinderman na Univerzitetu u Minhenu. Mada zanemarena u teorijskim pregledima iz oblasti, jednim delom i zbog jezičkih barijera, ova škola je implicitni analitički okvir velikog broja praktično orijentisanih studija. Preglednost i jezgrovitost konstelacione analize predstavljeni su kroz mali broj elemenata: sistem, percepcije, moć, interesi, norme i strategije. Sinoptički neorealizam je, ipak, značajno "probio" referentni okvir strukturalnog neorealizma u pravcu savremenih konstruktivističkih i kritičkih pristupa međunarodnim odnosima, sa svim prednostima i rizicima koje to nosi.

Ključne reči: međunarodni odnosi, sinopsis, konstelacija, sistem, percepcije, moć, interesi, norme, strategije, interakcije, neutralnost, multidisciplinarnost.

${ }^{1}$ Žaklina Novičić, naučni saradnik, Institut za međunarodnu politiku i privredu, Beograd, e-mail: zaklina@diplomacy.bg.ac.rs

Isidora Pop-Lazić, istraživač-pripravnik, Institut za međunarodnu politiku i privredu, Beograd, e-mail: isidora@diplomacy.bg.ac.rs

Rad je nastao u okviru projekta „Srbija i izazovi u međunarodnim odnosima 2020. godine“ , koji finansira Ministarstvo prosvete, nauke i tehnološkog razvoja Republike Srbije, a realizuje Institut za međunarodnu politiku i privredu tokom 2020. godine. 


\section{Praksa, politika, sistem i strukturacija u međunarodnim odnosima}

Sinoptički neorealizam je pristup proučavanju međunarodnih odnosa formulisan krajem sedamdesetih godina prošlog veka u Nemačkoj od strane Gotfrida-Karla Kindermana (Gottfried-Karl Kindermann, 1926-) kao kritika i dalja razrada klasičnog realističkog pristupa Hansa J. Morgentaua (Hans J. Morgenthau, 1904-1980). ${ }^{2}$ Osnove pristupa postavljene su zbornikom radova pod naslovom "Osnovni elementi svetske politike" iz 1976. godine, a narednih godina pokrenut je seminar za međunarodnu politiku na Univerzitetu u Minhenu, gde će nadalje biti centar tzv. Minhenske škole neorealizma u međunarodnim odnosima. ${ }^{3}$ Tih godina objavljena je u Americi "Teorija međunarodnih odnosa" (1979) Keneta N. Volca (Kenneth N. Waltz, 1924-2013), knjiga koja je uskoro stekla svetsku slavu i status nezaobilaznog štiva u disciplini, za razliku od nemačkog pandana koji ostaje u njegovoj senci. ${ }^{4}$ Zajednička odlika svih realističkih pristupa (klasičnog, sinoptičkog i strukturalnog) jeste njihova orijentacija na dato(st) u međunarodnim odnosima - u smislu konkretne stvarnosti, uz jasno razlikovanje dimenzije poželjnog i onoga „„što bi trebalo" da bude. Za razliku od drugih, sinoptički (neo)realizam Kindermana nije pretendovao da bude nova opšta teorija međunarodnih odnosa, već se predstavio kao empirijsko-analitički pristup orijentisan na praksu, koji teoriju posmatra kao integracionu ili sinoptičku disciplinu, a konstelacionu analizu kao glavnu metodu proučavanja međunarodnih odnosa i spoljne politike država.

Pragmatičnost $\mathrm{i}$ korisnost kao „razumno merilo" u proceni načina sticanja znanja o materiji koja je vrlo složena, kao što su to međunarodna i spoljna politika, trebalo bi da daju odgovor na pitanje da li se mogu dobiti korisni odgovori koji ,,intelektualno i pragmatično odgovaraju zahtevima praktičnog uma", kako je istakao Morgentau u predgovoru pomenutog utemeljivačkog zbornika sinoptičkog neorealizma: „Filozofski posmatrano, ono inspiriše našu neprekidnu težnju ka sve većem znanju o uslovima ljudskog postojanja u

\footnotetext{
${ }^{2}$ Morgentau je bio Kindermanov mentor na Univerzitetu u Čikagu. Više bibliografskih podataka u: Alexander Siedschlag, "Gottfried-Karl Kindermann, Grundüberzeugungen, Werdegang und Wirken," ins "Realistische Perspektiven internationaler Politik: Festschrift für Gottfried-Karl Kindermann zum 75. Geburtstag," Alexander Siedschlag (Hg.), Opladen: Leske + Budrich, 2001, S. 235-240.

${ }^{3}$ Grundelemente der Weltpolitik: Eine Einführung, Gottfried-Karl Kindermann (Hrsg.), München, 1976 [3. Auflage 1986]. Naziv „sinoptički neorealizam” minhenskom pristupu kasnije će dati Rajnhard Majer-Valzer u želji da istakne njegovu preglednost i jezgrovitost. V. Reinhard Meier-Walser, "Neorealismus ist mehr als Waltz - Der Synoptische Realismus des Münchner Ansatzes", in: Zeitschrift für Internationale Beziehungen, Vol. 1, No. 1, 1994, S. 115-126.

${ }^{4}$ Kenneth N. Waltz, Theory of International Politics, Reading, Mass.: Addison-Wesley, 1979.
} 
okruženju koje oblikuju ljudski odnosi. Pragmatično posmatrano, naše merilo evaluacije priznaje ograničenost racionalne analize i pouzdanih prognoza međunarodne politike zbog njihove složenosti i nesigurnosti." ${ }^{5}$

Dok je kod Morgentaua ključni pojam bila „moć u smislu interesa” urođena ljudskoj prirodi (animus dominandi), Kinderman je, isto kao i Volc, odstupio od njega u korist jednog "relativizovanog razumevanja”" ${ }^{6}$ Kao sredstvo ostvarenja vlastitih interesa u situacijama nadmetanja, moć je kod Kindermana polimorfna i višeslojna kategorija, pri čemu se, po pravilu, potreba za njom povećava sa povećanjem obima ciljeva. ${ }^{7}$ Centralni pojam kod Kindermana je sam pojam ",politike”, funkcionalno shvaćen i empirijski određen kao "odlučivanje u javnim poslovima" usmereno na akciju. ${ }^{8} \mathrm{Uz}$ to, i Kinderman i Volc su razlikovali sistem države i sistem međunarodne politike prema principu uređenja: zatvorena, piramidalna hijerarhijska organizacija države sa samo jednim legitimnim centrom odlučivanja, s jedne strane, i otvoren, policentričan sistem međunarodne politike bez središnjeg upravljačkog tela i izvršnog pravnog sistema, s druge strane. ${ }^{9}$

Volcov strukturalni neorealizam je, međutim, neuporedivo veći prioritet davao strukturi međunarodnog sistema (isključivo sastavljenoj od država) u smislu relevantnosti za ponašanje država. Za Minhensku školu ta isključivost vodi „izobličavanju koje nadilazi okvir legitimne apstrakcije stvarnosti i daje 'nerealnu' sliku međunarodne politike", zbog čega u analizu uvodi i unutrašnje strukture država, nedržavne aktere, psihološko-kognitivnu dimenziju

${ }^{5}$ Hans J. Morgenthau, “Geleitwort”, in Grundelemente der Weltpolitik, op. cit., S. 49-50.

${ }^{6}$ Prema: Reinhard Meier-Walser, "Neorealismus ist mehr als Waltz", op. cit., S. 122. V. Hans J. Morgenthau, Politics Among Nations: The Struggle for Power and Peace, New York: Knopf, 1948.

${ }^{7}$ Up. Gottfried-Karl Kindermann, "Zum Selbstverständnis des neorealistischen Ansatzes", in Grundelemente der Weltpolitik, op. cit., S. 19; Kenneth N. Waltz, "Realist Thought and Neorealist Theory", Journal of International Affairs, Vol. 44, No. 1, 1990, p. 36 .

${ }^{8}$ Gottfried-Karl Kindermann, "Internationale Politik in Theorie, Analyse und Praxis", in Grundelemente der Weltpolitik, in Grundelemente der Weltpolitik, op. cit., S. 70-72. Up. Gottfried-Karl Kindermann, "Klassischer Realismus und Synoptischer Neorealismus", ins Handbuch der Internationalen Politik, Carlo Masala, Frank Sauer and Andreas Wilhelm (Hrsg.), VS Verlag für Sozialwissenschaften, Wiesbaden 2010, S. 48-49.

${ }^{9}$ Up. Gottfried-Karl Kindermann, “Zum Selbstverständnis des neorealistischen Ansatzes", op. cit., S. 17, 27; Kenneth N. Waltz, Theory of International Politics, op. cit., pp. 79-128. Prema Volcu, kvalitet koji obeležava anarhiju je načelo samopomoći, a rezultat je stvaranje „ravnoteže snaga” kao međunarodnog ekvivalenta unutrašnjem načelu podele vlasti. Postoji paralela između između dva autora i u pogledu tumačenja nastanka međunarodne strukture: iz interakcije država (Volc), odnosno iz međusobno povezanih skupova i ponašanja (Kinderman). 
stvarnosti i, generalno, teži jednoj „,konceptualnoj slici elemenata, polja sile i procesa globalnih političkih događaja koji odgovaraju stvarnosti” ${ }^{10}$ Volcova ontološka „oskudnost" pokrenula je rasprave o nivoima analize međunarodnih odnosa koje traju do današnjih dana. ${ }^{11}$ Baveći se ne samo sistemima relevantnim za konstelaciju, već i glavnim kanalima i procesima njihovog međusobnog uticaja, što danas teorija međunarodne politike prepoznaje kao proces strukturiranja i strukturalne efekte, Kinderman je prejudicirao jednu važnu temu postrealističke i kritičke debate $\mathrm{u}$ međunarodnim odnosima. ${ }^{12}$

Jasna razlika između Volcovog strukturalnog i Kindermanovog sinoptičkog neorealizma postoji i u pogledu načina sticanja saznanja. Dok sinoptički neorealizam koristi istorijske analogije kao sastavni deo teorije iz koje onda izvodi hipoteze - dakle indukciju (kao i klasični realizam), Volc je koristio metodu (modifikovane) dedukcije, objašnjavajući da ", [t]vrditi da je moguće doći induktivno do teorije, znači tvrditi da se mogu razumeti pojave pre nego što se stvore sredstva za njihovo objašnjenje." ${ }^{13} \mathrm{U}$ svakom slučaju, i jedan i drugi oblik neorealizma teže konstrukciji modela složene stvarnosti, što je posao neizbežno povezan sa simplifikacijama.

U Kindermanovom modelu, u prvobitnoj verziji konstelacione analize, istaknuto je šest tzv. kvazidijagnostičkih kodeterminanti, odnosno ciljeva $\mathrm{i}$ pitanja: sistem, percepcije, moć, interesi, norme i strategije. Slika 1 daje pojednostavljeni prikaz ovog modela i najsažetiju predstavu njegovog sadržaja (ovde u obliku trilateralne konstelacije). Kindermanovi sledbenici u okviru Minhenske škole su, kao i on sam, kasnije revidirali početni model dodavanjem novih kategorija čime je, međutim, razvrstavanje kategorija u celini postajalo manje jasno. ${ }^{14} \mathrm{U}$ daljem tekstu najpre se uopšteno izlažu

${ }^{10}$ Reinhard C. Meier-Walser, "Die wissenschaftliche Untersuchung internationaler Politik - Struktureller Neorealismus, die 'Münchner Schule' und das Verfahren der 'Internationalen Konstellationsanalyse'," Aktuelle Analysen, Hanns Seidel Stiftung, Akademie für Politik und Zeitgeschehen, Band 35, 2005, München, S. 25-26; prema: Gottfried-Karl Kindermann, "Klassischer Realismus und Synoptischer Neorealismus", op. cit., S. 47.

${ }^{11}$ V. Žaklina Novičić, Neorealizam Keneta Volca: Analiza strukturalne teorije međunarodne politike, Institut za međunarodnu politiku i privredu, Beograd, 2009; Žaklina Novičić, „Kenneth Waltz i neorealizam”, u Teorije međunarodnih odnosa: Realizam, Dejan Jović (ur.), Politička kultura, Zagreb, 2013, str. 264-288.

${ }^{12}$ Alexander Siedschlag, "Einführung - Internationale Politik als skeptische Gegenwartswissenschaft und die Münchner Schule des Neorealismus", in Realistische Perspektiven internationaler Politik, op. cit., S. 46-48.

${ }^{13}$ Kenneth N. Waltz, Theory of International Politics, op. cit., p. 7; Cf. Kenneth N. Waltz, "Realist Thought and Neorealist Theory", op. cit., p. 33.

${ }^{14}$ V. Alexander Siedschlag, "Einführung", op. cit., S. 45-62; Reinhard Meier-Walser, "Neorealismus ist mehr als Waltz - Der Synoptische Realismus des Münchner 8 Ansatzes", op. cit., S. 115-126. 
osnovna polazišta metodologije konstelacione analize, da bi se potom ona razložila na sastavne elemete koji vode stvaranju sinopsisa konstelacione analize međunarodnih odnosa $u$ Kindermanovom delu.

Slika 1: Model trilateralne konstelacije prema Kindermanu

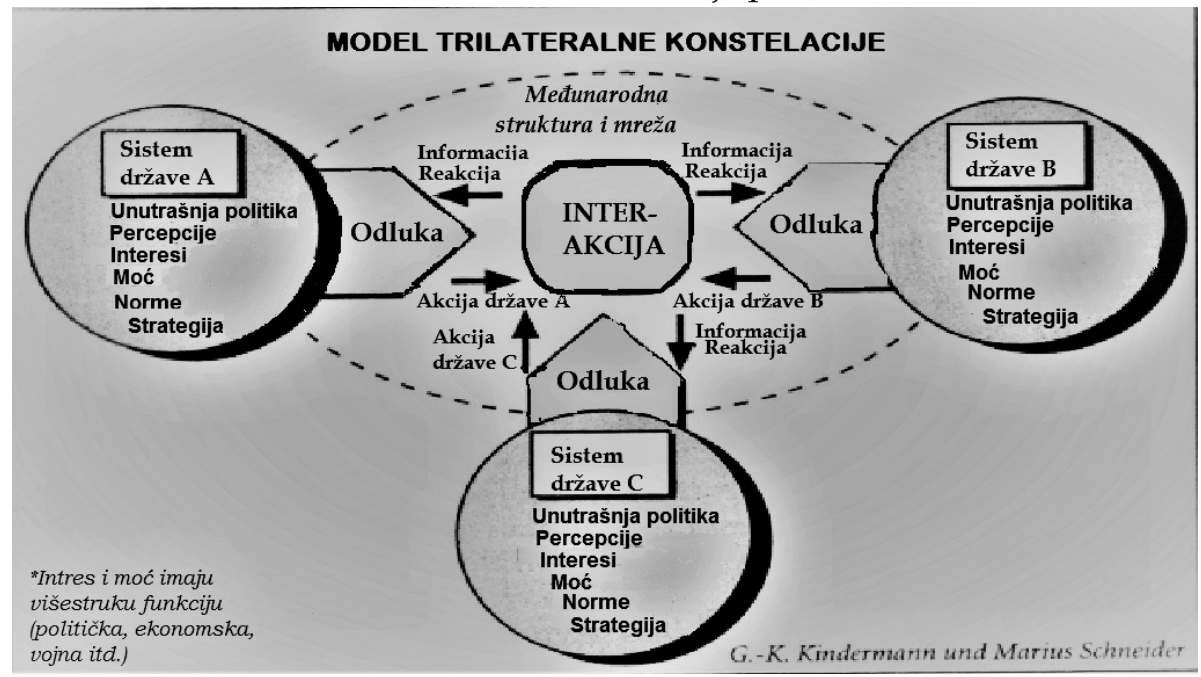

Izvor: Gottfried-Karl Kindermann, “Das Verhalten von Staaten: Zur Methodik der Internationalen Konstellationsanalyse, dem Analyseverfahren der Münchner Schule des Neorealismus", in Europa und die USA: Transatlantische Beziehungen im Spannungsfeld von Regionalisierung und Globalisierung, Reinhard C. Meier-Walser und Susanne Luther (Hrsg.), München, 2002, S. 128. ${ }^{15}$

\section{Metodologija konstelacione analize}

Načelno se mogu izdvojiti dva osnovna metodološka cilja sinoptičkog neorealizma: ideološka i vrednosna nepristrasnost, kao i nedogmatski pogled na ostale društvene nauke. Glavni metodološki i didaktički interes za Kindermana bila je izrada ideološki i vrednosno neutralnog sistema analize i metodologije. ${ }^{16} \mathrm{U}$ tom smislu, on se zalagao za nezavisnost naučnika od partija i klanova, a protiv oportunizma i politizovanja nauke o politici, polazeći od Veberovog diktuma da „ličnost" u naučnom polju mora „da služi samo nauci". ${ }^{17}$

${ }^{15}$ Navedeno u: Reinhard C. Meier-Walser, "Methodik der neorealistischen Konstellationsanalyse", in Handbuch der Internationalen Politik, op. cit., S. 233. Prevod: Ž. Novičić i I. Pop-Lazić.

${ }^{16}$ Gottfried-Karl Kindermann, "Klassischer Realismus und Synoptischer Neorealismus", op. cit., S. 50-51.

17 “'Persönlichkeit' auf wissenschaftlichem Gebiet hat nur der, der rein der Sache dient". Citat: Max Weber, Wissenschaft als Beruf, Duncker \& Humblot, München, 
Mada je na području naučnog proučavanja politike posebno teško odbaciti lične vrednosne procene, verovanja i pretpostavke konteksta (često se to čak ni ne pokušava), od naučnika se traži da barem bude jasan o tim osnovnim ličnim dispozicijama kako rezultat istraživanja ne bi bio podsvesno krivotvoren. ${ }^{18} \mathrm{U}$ Nemačkoj je takav pristup ukorenjen i u tradiciji sinoptičke nauke „Frajburške škole" Arnolda Bergštraesera (Arnold Bergstraesser, 1896-1964), koji je pokušao da zasnuje naučno bavljenje međunarodnom politikom - ne kao pitanja stava, već kao stvar nedoktrinarnog pogleda na stvarnost odvojenu od idealizma. ${ }^{19}$

Iz Bergštraeserovog kritičkog preispitivanja samog naučnika usledio je i nedogmatski pogled izvan vlastitog predmeta i potreba za "sociološkim obogaćivanjem" politikologije, što je on učinio istraživanjem savremenih kultura i sveukupne sociološke dinamike. Slično tome, Kinderman je usvojio „podelu rada" u nauci i stalni pogled izvan svoje oblasti - na političke nauke u celini, međunarodno pravo, političku istoriju i istoriju ideja, komparativnu politologiju, ustavnu istoriju, političke sisteme, spoljnu politiku državnika, procese ujedinjenja, upotrebu sile itd. ${ }^{20}$ Taj "nužni diverzitet" nauka, (međunarodno) politička teorija trebalo bi da "koordinira i da napravi sinopsis svih rezultata istraživanja poddisciplina", sa fokusom $u$, jednom opštem i integrativnom interesu za znanjem", pa se metoda sinoptičke nauke nužno shvata kao "metoda integracije" - "suštinski kontrapunkt diferencijaciji poddisciplina".$^{21}$

U konkretnom smislu, to dalje znači da osnovnu metodološku orijentaciju Minhenske škole neorealizma predstavlja integracija različitih objašnjavajućih faktora iz šireg konteksta problema. Analiza političkog delovanja se, dakle, fokusira na celokupni kontekst uzročnih odnosa, a ne samo na linearne lance delovanja: teži se tipičnim, ne samo povremeno zapaženim „problemskim konstelacijama” koje se ponavljaju. Metoda konstelacione analize izvorno je istorijska analogija, a sistemsko uspoređivanje istorijskog iskustva vodi njegovom tipologizovanju, i obratno,

1919. Up. Alexander Siedschlag, “Gottfried-Karl Kindermann, Grundüberzeugungen, Werdegang und Wirken," op. cit., S. 235.

${ }^{18}$ Up. Alexander Siedschlag, "Einführung", op. cit., S. 75.

${ }^{19}$ Osnov ove orijentacije postavljen je u rukopisu "Značenje i granice razumevanja među narodima" iz 1930. godine. Arnold Bergstraesser, Sinn und Grenzen der Verständigung zwischen Nationen, München, 1930.

${ }^{20}$ Gottfried-Karl Kindermann, "Konstellationsanalyse, synoptische Methode, Interessenanalyse", in Analyse internationaler Beziehungen: Methoden, Instrumente, Darstellungen, Jürgen Beller, Wichard Woyke (Hg.), Opladen: Leske u. Budrich, 1989, S. 99-109. Kinderman se posebno zanimao za istočnoazijsku pacifičku oblast i njenu noviju istoriju, zatim za politiku ponovnog ujedinjenja podeljenih zemalja, kao i politički sistem u Austriji ili važnost razumevanja sveta i ideologije za politiku u istočnoj Aziji, posebno za kinesko-sovjetske odnose.

$10{ }^{21}$ Ibid. 
povezivanju sa empirijskom stvarnošću. Konstelaciona analiza se izvodi i uz pomoć institucionalističkih koncepcija, kao što je "zavisnosti od puta" (eng. path dependency), što upućuje na uzročno posledičnu vezu sadašnjih od prošlih odluka. ${ }^{22}$

Tipovi političkog delovanja mogu da se povežu samo sa određenom epohom - u sinoptičkom neorealizmu nema oslanjanja na dispozicije koje su iznad istorije, niti strukturne parametre. Pretpostavlja se da interese uvek odlikuje vezanost za određenu lokaciju, kao i određena subjektivnost. Oni proizlaze iz percepcija (ponekad tragičnih zabluda), svetonazora i vrednosti, ali minhenski neorealizam ne razmatra vrednosti same per se, jer smatra neodgovornim preporučivanje primene normativnih koncepata neprilagođenih specifičnim okolnostima. ${ }^{23}$

U navedenom kontekstu se, korak po korak, iz istorijski orijentisanih pojedinačnih studija slučaja izvodi analitički instrumentarijum koji sadrži karakteristične činioce motivacije i uslova spoljnopolitičke aktivnosti. Primenjuje se višestruka perspektiva (multiperspektivnost), odnosno sagledavanje interesantnih činjenica iz različitih uglova - sa različitih analitičkih nivoa (npr. podnacionalni, nacionalni, regionalni, globalni), od strane različitih učesnika ili iz perspektive raznih kompleksa pitanja koji su uzastopno obrađeni u konstelacijskoj analizi (npr. analiza ponašanja, normi, moći, interesa itd.). Na kraju se izvrši sinoptička i uzročna evaluacija međuzavisnosti između tih snaga. ${ }^{24}$

Ukratko, kognitivni preduslovi analize konstelacije podrazumevaju: a) ograničavanje predmeta analize u pogledu vremena i strukture problema; b) izlaganje istorijata analiziranog odnosa međuzavisnosti relevantnog za konstelaciju; c) operacionalizacija analitičkog kategorijskog aparata; g) konačno, izrada i predstavljanje sinopsisa konstelacione analize. ${ }^{25}$

\section{Elementi konstelacione analize $i$ sinopsis}

Ranije je navedeno da se ciljevi i pitanja koje postavlja konstelaciona analiza odnose na: sistem, percepcije, moć, interese, norme i strategije. Kategorija "odluke" dodata je ovde na osnovu daljeg razvoja konstelacione analize, ali nje nema u izvornom obliku. Takođe, i sam Kinderman je neke

${ }^{22}$ V. Alexander Siedschlag, "Einführung", op. cit., S. 45-46.

${ }^{23}$ Ibid., S. 36.

${ }^{24}$ Gottfried-Karl Kindermann, "Zur Methodik der Internationalen Konstellationsanalyse", in Grundelemente der Weltpolitik, op. cit., S. 139-143.

${ }^{25}$ Gottfried-Karl Kindermann, "Internationale Politik in Theorie, Analyse und Praxis", op. cit., 59-105. Najkraći izraz ovih zahteva u: Reinhard C. Meier-Walser, "Methodik der neorealistischen Konstellationsanalyse", op. cit., S. 227-235. 
kategorije spajao i odvajao, na primer „moć” i „interes”, što ukazuje na pojmovno preplitanje i stalni rizik ,p probijanja” početnog referentnog oblika koje može dovesti do nejasnih konstrukcija. U najkraćem će dalje biti predstavljen sadržaj osnovnih kodeterminanti analize konstelacije.

\section{Sistem}

U konstelacionoj analizi Minhenske škole razmatraju se, kao elementi „sistema”, države i nedržavni akteri: savezi država, kao i nadnacionalni i podnacionalni akteri. Svi oni mogu da utiču na procese interakcija i dinamiku međunarodne politike. Države se shvataju kao monocentrični sistemi, a mogu se posmatrati kao sistemi kolektivne akcije ili dalje mogu biti analitički raščlanjeni na najznačajnije nosioce spoljnopolitičkog odlučivanja, mehanizme odlučivanja, kao i spoljnopolitičku infrastrukturu (stranke, opozicija, vojska, službe, lobiji, mediji, crkve, javnosti itd.). Referentni sistemi za konstelacionu analizu su i „drugi sistemi akcija”: međunarodni sistem kao takav, odnosni regionalni sistem, eventualno i međunarodne organizacije i drugi oblici saradnje, nevladine organizacije, i sl. Mada međunarodna politika predstavlja "anarhičan” sistem - sistem suverenih država, postoje neki elementi delimičnog poretka - države same definišu svoje interese, u skladu s njima formiraju saveze očekujući koristi kao kompenzaciju za ugovorene obaveze koje im ograničavaju slobodu delovanja. ${ }^{26}$

Navedene stavove zastupaju manje-više, pored sinoptičkog realizma, i strukturalni i klasični realizam, s tim što potonja dva ne tretiraju u analizi nedržavne aktere. Sinoptički neorealizam ispituje oba nivoa (država, međunarodna politika) u njihovoj međuzavisnosti, na čijem preseku stoji spoljna politika država kao "Janusova glava”, koja istovremeno mora da gleda u oba smera kako bi bila delotvorna. ${ }^{27}$ Sa metaforom glave Janusa, Kinderman i minhenski neorealizam stupili su direktno $u$ ono što danas zovemo postrealističkom ili kritičkom raspravom o nivoima analize međunarodne politike, naznačenoj ranije $\mathrm{u}$ tekstu $\mathrm{u}$ razlikama između sinoptičkog neorealizma i strukturalnog neorealizma Keneta Volca. Na osnovu poznate Volcove terminologije o tri nivoa analize (čovek, država i sistem država), konstelaciona analiza bila bi „realizam sa više slika” (multiimage-Realismus) ${ }^{28} \mathrm{Iz}$ istog razloga, Kinderman i njegovi sledbenici odbijaju

${ }^{26}$ Gottfried-Karl Kindermann, Grundelemente der Weltpolitik: Eine Einführung, op. cit., S. $11-47,76-80$.

27 "Münchner Neorealismus in Theorie und Praxis: 'Außenpolitik ist ein Janus-Kopf'", Navedeno u: Alexander Siedschlag, Neorealismus, Neoliberalismus und postinternationale Politik: Beispiel internationale Sicherheit - Theoretische Bestandsaufnahme und Evaluation", Springer Fachmedien Wiesbaden, Opladen, 1997, S. 71-72.

${ }^{28}$ Alexander Siedschlag, Neorealismus, Neoliberalismus und postinternationale Politik, op. 12 cit., S. 67-68. 
da se izjasne između mikro ili makro pristupa međunarodnim odnosima, kao što je to slučaj sa drugim vrstama realizma. ${ }^{29}$

Konačno, ovim su pored strukture međunarodne politike $u$ analizu uvedeni i istaknuti i procesi tzv. strukturiranja, što je predmetni sadržaj međunarodnih konstuktivističkih i kritičkih teorija. Minhenska škola u neku ruku i predstavlja njihovu sintezu sa realizmom, a u novijim konstelacionim analizama pod ovom analitičkom stavkom proces strukturiranja je izričito i naveden. ${ }^{30}$ To podrazumeva i prateće nedoslednosti ovog pristupa (npr. narativizam), o kojima će u zaključnom delu teksta biti više reči. To je, takođe, odlika i narednih faza konstelacione analize.

\section{Percepcije}

Poseban značaj u konstelacionoj analizi ima kognitivna sfera političke delatnosti. Polazi se od toga da većina pojava u politici i istoriji, od političkih stranaka do odnosa moći - nisu fizički odredive, već su zapravo misaone. Sinoptički neorealizam izričito naglašava problem procene situacije: pretpostavlja se da postoji pluralizam percepcije, odnosno da svaki akter drugačije procenjuje kako sopstvenu, tako i situaciju ostalih važnih aktera. Osnovna hipoteza je da se međunarodni procesi i ponašanje aktera ne mogu adekvatno objasniti kao procesi prilagođavanja strukturalnim političkim tendencijama, već se uvek temelje na definicijama stvarnosti koje zavise od percepcija i samim tim su i selektivne. ${ }^{31}$

$\mathrm{Na}$ osnovu „konstrukcija stvarnosti”, relevantni akteri određuju svoje interese i donose odluke. Subjektivne procene objektivne stvarnosti i pluralizam percepcija svojstveni su svakoj konstelaciji, a napetost između percepcije i stvarnosti važan je izvor međunarodne dinamike. Percepcije stvarnosti uslovljene su informacijama - obrađenim i sačuvanim, zatim vaspitanjem, obrazovanjem, iskustvom, svetonazorima, personalitetima, životnim iskustvom itd. Percepcije ovde, dakle, igraju formativnu ulogu. Pored toga, uporedni pregled percepcija aktera ublažava subjektivnost analize i time, u konstelacionoj analizi, predstavlja kontrolni faktor ljudskog (time i spoljnopolitičkog) ponašanja. U najkraćem, društveno-naučni temelj

${ }^{29}$ Ibid., S. 70-71. Morgentau je, na primer, bio jasne mikro orijentacije - posmatrao je konkretne političke akcije u njihovim opaženim dejstvima; dok je, s druge strane, Volcov pristup bio makro analitički - on strukturu međunarodnog sistema uzima kao nezavisnu opštu varijablu.

${ }^{30}$ Tako naslov „Struktura i strukturiranje” nalazimo kod: Alexander Siedschlag, "Einführung", op. cit., S. 76.

${ }^{31}$ Gottfried-Karl Kindermann, "Internationale Politik in Theorie, Analyse und Praxis", op. cit., S. 82-83. 
minhenskog pristupa odgovara "Tomasovoj teoremi”: „Ako akteri neku situaciju procenjuju kao stvarnu, onda su i njene posledice stvarne” ${ }^{32}$

Moć

U konstelacionoj analizi „moć” se posmatra kao promenjiva međuzavisnost psiholoških, društveno-političkih i materijalnih komponenti. Ukupno stanje moći države proizlazi iz kombinacije vojno-strateških, ekonomsko-tehnoloških, geografsko-demografskih i političko-moralnih činilaca (tj. iz unutrašnje političke koherentnosti sistema, verodostojnosti ponašanja, podrške spoljnih aktera političkom kursu zemlje itd.). Pri tome, pravi se razlika između „potencijalne” i „trenutne” moći aktera; između stanja moći i sredstava moći koje su odlučioci spremni da koriste; kao i između sredstava moći i obima delovanja moći koju je akter voljan i sposoban da upotrebi u određenoj situaciji kako bi ostvario svoje interese. „Moć” zapravo nema opštu političku virulenciju, već se razume, zavisno od situacije, na specifičan način i aktuelizuje se u specifičnom obliku. Na sličan način "moć" posmatraju i noviji kritičko-sociološki pristupi u međunarodnim odnosima, kao i veliki delovi neoliberalizma, $u$ širem smislu i institucionalizma. Efikasnost, delotvornost moći kojoj se teži u neoliberalizmu na primer, uvek zavisi od konkretne političke situacije, odnosno od toga šta se može učiniti sa njom. ${ }^{33}$

\section{Interesi}

Konstelaciona analiza postavlja pitanje o koncepcijama interesa spoljnopolitičkih elita koje su ograničene situacijom i subjektivne prirode, dakle ne o „objektivnim interesima” (u smislu „državnog razloga” ili „nacionalnog interesa”). Interesi su ovde shvaćeni kao subjektivne varijable, ono što političari i vlade kao takvo definišu i usvoje kao osnovu svog spoljnopolitičkog delovanja, pri čemu, ponekad, mogu biti tragično izobličeni nerazumevanjem situacije. Interesi podrazumevaju usmeravanje volje ka delovanju u vezi sa nekim objektom, odnosno sposobnost sprovođenja vlastite volje, što ih čini dinamičnom kategorijom. ${ }^{34}$

Treba naglasiti da je Minhenska škola generalno skeptična prema univerzalnim interesima i proglašavanju univerzalnih ideja i vrednosti nacionalnim interesom. Smatra se da, dugoročno, uverljiv i izvodljiv može

\footnotetext{
${ }^{32}$ Ibid., William I. Thomas - jedan je od prethodnika simboličkog interakcionizma u sociologiji. V. Alexander Siedschlag, “Einführung”, op. cit., S. 51-52.

${ }^{33}$ Ibid., S. 57-58. V. Gottfried-Karl Kindermann, "Zur Methodik der Internationalen Konstellationsanalyse", op. cit., S. 117-124.
}

$14 \sqrt{34}$ Ibid. 
biti samo nacionalni interes kao etička odgovornost, kao politika orijentisana na fakte i probleme, a ne na poboljšanje sveta - što se teško može izmeriti političkim kriterijima uspeha. ${ }^{35}$ Sličan obazriv stav (koji možemo nazvati prudencijalizmom) jezgrovito je sažeo Morgentau: „Ne postoji politički moral bez opreznosti (nem. Klugheit), odnosno bez razmatranja političkih posledica naizgled moralno opravdanog pristupa. Stoga realizam smatra opreznost - vaganje posledica alternativnih političkih akcija - najvećom vrlinom politike." ${ }^{36}$ Najveća opasnost u shvatanju nacionalnog interesa vidi se u izražavanju čistih osećanja ili njihovom unošenju u politički program bez uzmanja u obzir pojedinačnog slučaja, zahteva za međunarodnim kompromisom i, pre svega, dostupnih (ili nedostupnih) sredstava za njihovu kredibilnu implementaciju. ${ }^{37}$

\section{Norme}

Proučavanje pravnog položaj država uključenih u konstelaciju takođe je deo (konstelacione) analize. Pored pravne i normativne analize, ovaj postupak obuhvata i ideološke i etičke norme i njihovu relativnu političku vrednost. Između njih, s jedne strane, i političkih i ekonomskih koristi, s druge strane, nastaju tenzije i problemi za nosioce spoljnopolitičkih odluka kada biraju različite opcije ponašanja. Ipak, minhenski neorealizam, kao i realizam uopšte, ne pridaje apsolutnu vrednost normama. Zbog anarhične strukture međunarodnog sistema, samo pravni entiteti mogu učiniti politički efikasnim međunarodne norme. Čak ni tada, dejstvo nemaju norme per se, već $u$ obliku $u$ kojem ih tumače učesnici $u$ interakciji na jedan interesno usmeren način. Time sinoptički realizam dolazi do hipoteze da nivo opšte normativne obavezujuće snage međunarodnih ugovora nije konstantan, „,već zavisi od promenjivog nivoa intenziteta interesa zemalja potpisnica koji ga stvaraju i podržavaju" ${ }^{\prime 8}$

\section{Strategije}

Konstelaciona analiza uključuje i pitanja o strategijama, kao načinima i sredstvima pomoću kojih se implementiraju odluke. Strategije dovode do obrazaca saradnje, sukoba ili neutralnosti, a na osnovu interesa, percepcija i

${ }^{35}$ Alexander Siedschlag, "Einführung", op. cit., S. 49-50.

${ }^{36}$ Hans J. Morgenthau, Macht und Frieden: Grundlegung einer Theorie der internationalen Politik, Gütersloh: Bertelsmann, 1963, S. 56.

${ }^{37}$ Alexander Siedschlag, "Einführung", op. cit., S. 49-50.

${ }^{38}$ Reinhard C. Meier-Walser, "Methodik der neorealistischen Konstellationsanalyse", op. cit., S. 232-234. V. Gottfried-Karl Kindermann, "Zur Methodik der Internationalen Konstellationsanalyse", op. cit., S. 130. 
strukture vlasti. Ključno pitanje je kako se strategije za praktičnu implementaciju političkih odluka oblikuju u ,institucionalnom okruženju” unutar kojeg se odvijaju. Pri tome se posmatraju različiti povratni efekti i polazi od toga da programi prošlih politika uslovljavaju trenutnu političku akciju i izbor sredstava (politike). Politički uslovi, koji su trenutno operativni, takođe mogu promeniti budućnost u meri u kojoj će zaoštriti ili oslabiti identitet aktera, podstaknuti očekivanja ili pomoći da se iskristališu novi motivi. Posledice, dakle, ne proizlaze samo iz materijalnih odluka već i odgovarajućih i odabranih strategija. ${ }^{39}$

\section{Odluke}

U daljem razvoju minhenskog neorealizma kao posebna kategorija dodato je „odlučivanje između formiranja volje i korigovanja volje” (nem. Willensbildung und Korrektur). ${ }^{40}$ Polazna pretpostavka je da političke odluke nisu izolovani događaji, već vremenski odloženi procesi čije rezultate bi trebalo tokom vremena osigurati na najbolji mogući način. Ako se pojave zahtevi za ispravljanjem (korekcijom) u smislu motivacionog razumevanja moći, postane jasno da se „racionalna” spoljnopolitička odluka ne može interno sprovesti. Budući da fenomeni političkog odlučivanja nisu linearni, već difuzni i gotovo turbulentni, svaka odluka predstavljala neki aspekt političke $\mathrm{i}$ istorijske stvarnosti $\mathrm{i}$, obratno, stvara potpuno nove situacije odlučivanja i često razgranata "stabla odluka”. ${ }^{41}$ Fundamentalno je to da se ovde odluke ne posmatraju kao jednokratni događaji, već kao procesi.

\section{Sinopsis}

Završni korak u konstelacionoj analizi (sinteza) zahteva sveobuhvatnu procenu dinamičke veze međuzavisnosti koja je rezultat interakcije elemenata konstelacije. Znanja stečena u prethodnim fazama rada sakupljaju se $\mathrm{u}$ idejnu skicu celokupne konstelacije, u kojoj se oni povezuju međusobno i posmatraju na integrisan način. ${ }^{42}$ Osnova za ispravan sinopsis je sistemsko združivanje pojedinačnih rezultata, tipološko isticanje procesa interakcije između različitih nivoa uzročnosti, iskoračivanje prema apstrakciji i generalizacija rezultata. ${ }^{43}$ Konkretno se ovi postupci sprovode u skladu sa

${ }^{39}$ Up. Gottfried-Karl Kindermann, "Zur Methodik der Internationalen Konstellationsanalyse", op. cit., S. 127-129.

${ }^{40}$ Alexander Siedschlag, "Einführung”, op. cit., S. 52-53.

${ }^{41}$ Alexander Siedschlag, Neorealismus, Neoliberalismus und postinternationale Politik, op. cit., S. 83-84.

${ }^{42}$ Gottfried-Karl Kindermann, “Zur Methodik der Internationalen Konstellationsanalyse", op. cit., S. 142.

$16{ }^{43}$ Alexander Siedschlag, "Einführung”, op. cit., S. 61-62. 
uputstvima koji su navedeni $\mathrm{u}$ početnom delu rada pod naslovom "Metodologija sinoptičke analize".

\section{Dalji razvoj i kritički osvrt na Minhensku školu neorealizma}

Predstavnici Minhenske škole i sinoptičkog neorealizma koji su dalje razvijali originalni Kindermanov pristup zamerali su mu da, uprkos funkcionalnom formiranju koncepcija i sistemskoj perspektivi, u krajnjem ipak ostaje fokusiran na statičke kategorije. Međusobne poveznice između kategorija konstelacione analize nije lako uočiti. Analiza sistema u konkretnim oblicima obično predstavlja prvenstveno formalnu strukturalnu sliku područja donošenja odluka i sprovođenja spoljne politike, dok analiza interesa pokazuje relevantne motivacione - strukture, a analiza moći ostaje, pre svega, analiza - strukture moći itd. Postavlja se i pitanje da li oslanjanje na stvaranje strukture konstelacije i zaključke istorijsko-strukturnih analogija dovodi do gubitka podataka i rizika da objašnjenja i analize budu nepotpuni. Pitanje je i to da li je konstelaciona analiza dovoljna i prikladna da bi se uzročno ispravno zabeležila struktura odnosa u sinopsisu svih pojedinačnih ispitivanja. ${ }^{44}$

Savremena konstelaciona analiza zamera utemeljivaču ovog modela istraživanja i to što, uprkos opredeljenju za multimetodičnost, analizu svodi na noviju istoriju, arhivska dokumenta i intervjue, pa se zato u novijim analizama koriste i drugi socijalno-psihološki, kulturološko-sociološki i teorijski modeli odlučivanja. Favoriziranje metode istorijske analogije $u$ praktičnoj primeni redovno teži narativizmu - obliku pseudo kauzaliteta koji „objašnjenja društvenih nauka želi da zameni fenomenološkim opisom spornih činjenica". ${ }^{45}$

Gore nabrojane, kao i druge nedostatke originalne konstelacione analize, pokušali su da otklone Kindermanovi naslednici „kroz četiri kanala” ${ }^{46}$ Prvi kanal je bio kritika originalnog pristupa: ispitivanje kontradikcija i intelektualnih rupa u njemu. Drugi kanal je ispunjavalo razmatranje iskustava stečenih prilikom empirijskih analiza koje su imale praktičnu vrednost konceptualnog okvira, kao i preispitivanje hipoteza i starog oblika konstelacione analize. Kao treći kanal revizije originalne konstelacione analize navodi se iskustvo rada u nastavi. Konačno, kao motivacija poslužila su i dalja metodološka razmatranja i inovacije.

Spomenućemo samo neke konkretne dalje razrade u okviru sinoptičkog neorealizma, budući da ovde nije moguća ni potrebna njihova detaljnija

${ }^{44}$ Up. Alexander Siedschlag, Neorealismus, Neoliberalismus und postinternationale Politik, op. cit., S. $67-68,123-124$.

${ }^{45}$ Ibid.

${ }^{46}$ Ibid., S. 38-39. 
razrada. Treba pomenuti dinamičku sistemsku teoriju i koncepciju haosa kod Aleksandra Zidšlaga (Alexander Siedschlag), kao i „Kelnsku školu” i tzv. konfiguracijski realizam Vernera Linka (Werner Link). ${ }^{47}$ Za navedene pokušaje daljeg razvoja minhenskog neorealizma, posebno njegove metodologije, presudan je bio uticaj neostrukturalnog realizma (Buzan, Jonesa, Little) i pokušaj da se u celini neorealizam oslobodi tendencije ka statičkim kategorijama i, pre svega, učini dostupnijim pomoću novih sistemsko-teorijskih koncepata. ${ }^{48}$

Nezadovoljstvo prosuđivanjem o spoljnopolitičkom ponašanju država i njihovoj međusobnoj interakciji na osnovu, uglavnom, pozicioniranja $u$ strukturi međunarodne politike nije nov fenomen, i otvoreno ostaje upitno da li je korisno odvajati druge elemente analize kao što su međunarodnopravni propisi ili ideološka i etička razmatranja i slično. I sam Kindermanov sinoptički neorealizam predstavlja odstupanje od teorijske rigoroznosti strukturalnog pristupa (Keneta Volca) i od insistiranja da se analiza međunarodne politike zadrži na sistemskim i strukturalnim faktorima. Podsećanja radi, mora se međutim istaći da se širenjem kategorija i metodoloških sredstava probija disciplinarni okvir međunarodnih odnosa i dovodi u pitanje disciplinarni identitet i autonomija ove istraživačke oblasti. Ako sociologija, istorija ili druge naučne oblasti drže ključ razumevanja međunarodnih odnosa, onda je ova disciplina suštinski pretvorena $u$ podskup kako ovih oblasti tako i politikologije uopšte i drugih društvenih nauka. ${ }^{49}$ Predmetno i metodološko širenje međunarodnih odnosa je delikatna, široko raspravljana i složena tema za koju ovde nema prostora niti potrebe, ali je prikladno podsetiti na upozorenja jednog od utemeljivača naučnog istraživanja međunarodnih odnosa, Stenlija Hofmana (Stanley Hoffmann) s kraja pedesetih godina prošlog veka da "[b]uvljak, međutim, nije disciplina” mada, svakako, ,[v]ećina (drugih) podoblasti ima šta da ponudi (međunarodnim odnosima)". ${ }^{50}$

Kindermanovi sledbenici zahtevali su i proširenje funkcije međunarodno političke teorije sa postupka objašnjenja na prognoze, predloge i političko savetovanje $\mathrm{u}$ kontekstu savremenih i terenskih istraživanja politike. ${ }^{51} \mathrm{Nije}$

${ }^{47}$ Werner Link, "Die Entwicklung des Ost-West-Konfliktes", in Einfuhrung in die Internationale Politik, M. Knapp and G. Krell (eds), 1996 (3rd edn), Munich, Vienna: Oldenbourg, pp. 242-274. Alexander Siedschlag, Chaos in der internatinoalen Politik, München, GRIN Verlag, 2000.

${ }^{48}$ Barry Buzan, Charles Jones and Richard Little, The Logic of Anarchy: Neorealism to Structural Realism, New York: Columbia University Press, 1993.

${ }^{49}$ Justin Rosenberg, "International Relations in the prison of political science", International Relations, 2016, Vol. 30, No. 2, pp. 127-153.

${ }^{50}$ Stanley Hoffmann, "International Relations: The Long Road to Theory", World Politics, Vol. 11, No. 3, 1959, p. 348.

${ }^{51}$ Alexander Siedschlag, "Einführung”, op. cit., S. 40. 
nova tema odnos između društvenih nauka generalno i javne politike odnos koji ostaje „zauvek eksplozivan”, niti je veliko otkriće to da postoje značajne razlike između kodeksa moralne odgovornosti $u$ dve oblasti. Recimo, ipak, da to lako može da navede na stranputicu kao što je upozoravao, na primer, i Hans Morgentau $u$ kontekstu kooptiranja američkih društvenih naučnika u „akademsko-politički kompleks”, što je, po njegovom mišljenju, uvelo SAD u močvaru Vijetnama. ${ }^{52}$

U samoj Nemačkoj, sinoptički neorealizam Minhenske škole prisutan je $\mathrm{u}$ velikom broju praktično orijentisanih političkih studija kao implicitni analitički okvir, mada se u velikim disciplinarnim "postrealističkim” raspravama nalazio samo na marginama. ${ }^{53}$ Ima onih koji lamentiraju nad time što su dostignuća realizma praktično zanemarena, ${ }^{54}$ ali ima i pronicljivijih viđenja da savremeni realizam u Nemačkoj ima gotovo dominantan status. ${ }^{55}$ Što se tiče velikih disciplinarnih debata o međunarodnim odnosima u zapadnom svetu generalno, teorijske postavke, metod i dometi Minhenskog neorealizma i konstelacione analize međunarodnih odnosa ostali su $u$ dobroj meri zanemareni i nepoznati stručnoj i široj javnosti, verovatno jednim delom zbog jezičkih barijera i ograničene pristupačnosti tekstova nemačkog porekla.

U svakom slučaju, konstelaciona analiza je legitiman i koristan pristup i čini se da nije pogrešno reći da joj se istraživački pristupi širom sveta spontano obraćaju - u smislu interdisciplinarnog umrežavanja, širine i preplitanja. Prepoznavanje te okolnosti, na kraju krajeva, motivisalo je i ovaj sažeti pokušaj da čitaoce u Srbiji upoznamo sa osnovama sinoptičkog neorealizma $u$ delima najpoznatijih članova Minhenske škole $u$ međunarodnim odnosima. Vredno pažnje bilo je to što su konstelaciona

${ }^{52}$ Hans J. Morgenthau, Truth and Power: Essays of a Decade, 1960-70, London, 1970, p. 14. Videti: William Wallace, "Truth and power, monks and technocrats: theory and practice in international relations", Review of international Studies, No. 22, 1996, pp.301-321. Spomenimo ovom prilikom i to da je kredibilitet istaknutog poznavaoca ove materije i više puta citiranog u ovom tekstu Aleksandra Sidšlaga narušila kontroverza $\mathrm{u}$ vezi sa optužbom za sukob interesa $\mathrm{u}$ kontekstu prihvatanja sponzorstva naučnih događaja od strane jednog austrijskog proizvođača vojne tehnologije. V. Internet: http://www.airpower.at/ua/20070604_siedschlag.htm

${ }^{53}$ V. Christoph Humrich, "Germany", in International Relations in Europe: Traditions, perspectives and destinations, Knud Erik Jørgensen and Tonny Brems Knudsen (eds), Routledge, 2006, pp. 72-99.

${ }^{54}$ Günther Hellmann, "Fur eine problemorientierte Grundlagenforschung: Kritik und Perspektiven der Disziplin 'Internationale Beziehungen' in Deutschland", Zeitschrift fur Internationale Beziehungen, Vo. 1, No. 1, 1994, pp. 65-90.

${ }^{55}$ Reinhard Meyers, “Weltmarkt oder Weltpolitik? Anmerkungen zur gegenwartigen Befindlichkeit der bundesrepublikanischen Lehre von den internationalen Beziehungen", Neue Politische Literatur, Vol. 31, No. 2, 1986, pp. 187-211. 
analiza i sinoptički neorealizam Minhenske škole još jednom istakli činjenicu da teorija i metodologija u naučnom izučavanju međunarodnih odnosa ne znače ni akademski luksuz, ni nebitne dodatke analize, već služe kao osnov delovanja i kontrolni metod u procesu razmišljanja utemeljenog na znanju i usmerenog ka dobijanju realističnih mentalnih slika ili modela stvarnosti.

\section{Literatura}

Bergstraesser, Arnold, Sinn und Grenzen der Verständigung zwischen Nationen, München, 1930.

Buzan, Barry, Charles Jones and Richard Little, The Logic of Anarchy: Neorealism to Structural Realism, New York: Columbia University Press, 1993.

Grundelemente der Weltpolitik: Eine Einführung, Gottfried-Karl Kindermann (Hrsg.), München, 1976 [3. Auflage 1986].

Hellmann, Günther, "Fur eine problemorientierte Grundlagenforschung: Kritik und Perspektiven der Disziplin 'Internationale Beziehungen' in Deutschland", Zeitschrift fur Internationale Beziehungen, Vo. 1, No. 1, 1994, pp. 65-90.

Hoffmann, Stanley, "International Relations: The Long Road to Theory", World Politics, Vol. 11, No. 3, 1959, pp. 346-377.

Humrich, Christoph, "Germany", in International Relations in Europe: Traditions, perspectives and destinations, Knud Erik Jørgensen and Tonny Brems Knudsen (eds), Routledge, 2006, pp. 72-99.

Kindermann, Gottfried-Karl, “Das Verhalten von Staaten: Zur Methodik der Internationalen Konstellationsanalyse, dem Analyseverfahren der Münchner Schule des Neorealismus", in Europa und die USA: Transatlantische Beziehungen im Spannungsfeld von Regionalisierung und Globalisierung, Reinhard C. Meier-Walser und Susanne Luther (Hrsg.), München, 2002, S. 124-133.

Kindermann, Gottfried-Karl, "Internationale Politik in Theorie, Analyse und Praxis", in Grundelemente der Weltpolitik: Eine Einführung, Gottfried-Karl Kindermann (Hrsg.), München, 1976 [3. Auflage 1986], S. 59-105.

Kindermann, Gottfried-Karl, "Klassischer Realismus und Synoptischer Neorealismus", in Handbuch der Internationalen Politik, Carlo Masala, Frank Sauer and Andreas Wilhelm (Hrsg.), VS Verlag für Sozialwissenschaften, Wiesbaden 2010, S. 46-52.

Kindermann, Gottfried-Karl, "Konstellationsanalyse, synoptische Methode, Interessenanalyse", in Analyse internationaler Beziehungen: Methoden, Instrumente, Darstellungen, Jürgen Beller, Wichard Woyke (Hg.), Opladen:

20 Leske u. Budrich, 1989, S. 99-109. 
Kindermann, Gottfried-Karl, "Zum Selbstverständnis des neorealistischen Ansatzes", in Grundelemente der Weltpolitik: Eine Einführung, GottfriedKarl Kindermann (Hrsg.), München, 1976 [3. Auflage 1986], S. 11-48.

Kindermann, Gottfried-Karl, "Zur Methodik der Internationalen Konstellationsanalyse", in Grundelemente der Weltpolitik: Eine Einführung, Gottfried-Karl Kindermann (Hrsg.), München, 1976 [3. Auflage 1986], S. 106-144.

Link, Werner, “Die Entwicklung des Ost-West-Konfliktes", in Einfuhrung in die Internationale Politik, M. Knapp and G. Krell (eds), 1996 (3rd edn), Munich, Vienna: Oldenbourg, pp. 242-274.

Meier-Walser, Reinhard C., "Die wissenschaftliche Untersuchung internationaler Politik - Struktureller Neorealismus, die 'Münchner Schule' und das Verfahren der 'Internationalen Konstellationsanalyse'," Aktuelle Analysen, Hanns Seidel Stiftung, Akademie für Politik und Zeitgeschehen, Band 35, 2005, München., S. 1-31.

Meier-Walser, Reinhard C., "Methodik der neorealistischen Konstellationsanalyse", in Handbuch der Internationalen Politik, Carlo Masala, Frank Sauer and Andreas Wilhelm (eds), VS Verlag für Sozialwissenschaften, Wiesbaden, 2010, S. 227-235.

Meier-Walser, Reinhard C., "Neorealismus ist mehr als Waltz - Der Synoptische Realismus des Münchner Ansatzes", in: Zeitschrift für Internationale Beziehungen, Vol. 1, No. 1, 1994, S. 115-126.

Meyers, Reinhard, "Weltmarkt oder Weltpolitik? Anmerkungen zur gegenwartigen Befindlichkeit der bundesrepublikanischen Lehre von den internationalen Beziehungen", Neue Politische Literatur, Vol. 31, No. 2, 1986, pp. 187-211.

Morgenthau, Hans J., "Geleitwort", in Grundelemente der Weltpolitik: Eine Einführung, Gottfried-Karl Kindermann (Hrsg.), München, 1976 [3. Auflage 1986], S. 49-50.

Morgenthau, Hans J., Macht und Frieden: Grundlegung einer Theorie der internationalen Politik, Gütersloh: Bertelsmann, 1963.

Morgenthau, Hans J., Politics Among Nations: The Struggle for Power and Peace, New York: Knopf, 1948.

Morgenthau, Hans J., Truth and Power: Essays of a Decade, 1960-70, London, 1970.

Novičić, Žaklina, „Kenneth Waltz i neorealizam”, u Teorije međunarodnih odnosa: Realizam, Dejan Jović (ur.), Politička kultura, Zagreb, 2013, str. 264-288.

Novičić, Žaklina, Neorealizam Keneta Volca: Analiza strukturalne teorije međunarodne politike, Institut za međunarodnu politiku i privredu, Beograd, 2009.

Rosenberg, Justin, "International Relations in the prison of political science", International Relations, 2016, Vol. 30, No. 2, pp. 127-153. 
Siedschlag, Alexander, "Einführung - Internationale Politik als skeptische Gegenwartswissenschaft und die Münchner Schule des Neorealismus", in Realistische Perspektiven internationaler Politik: Festschrift für GottfriedKarl Kindermann zum 75. Geburtstag, Alexander Siedschlag (Hg.), Opladen: Leske + Budrich, 2001, S. 13-66.

Siedschlag, Alexander, "Gottfried-Karl Kindermann, Grundüberzeugungen, Werdegang und Wirken", in Realistische Perspektiven internationaler Politik: Festschrift für Gottfried-Karl Kindermann zum 75. Geburtstag, Alexander Siedschlag (Hg.), Opladen: Leske + Budrich, 2001, S. 235-240.

Siedschlag, Alexander, Chaos in der internatinoalen Politik, München, GRIN Verlag, 2000.

Siedschlag, Alexander, Neorealismus, Neoliberalismus und postinternationale Politik: Beispiel internationale Sicherheit: Theoretische Bestandsaufnahme und Evaluation", Springer Fachmedien Wiesbaden, Opladen, 1997.

Wallace, William, "Truth and power, monks and technocrats: theory and practice in international relations", Review of international Studies, No. 22, 1996, pp. 301-321.

Waltz, Kenneth N., "Realist Thought and Neorealist Theory", Journal of International Affairs, Vol. 44, No. 1, 1990, pp. 21-37.

Waltz, Kenneth N., Theory of International Politics, Reading, Mass.: AddisonWesley, 1979.

Weber, Max, Wissenschaft als Beruf, Duncker \& Humblot, München, 1919.

\title{
SYNOPTIC NEOREALISM: A REVIEW OF THE MUNICH SCHOOL AND CONSTELLATION ANALYSIS OF INTERNATIONAL RELATIONS
}

\begin{abstract}
This paper presents a review of synoptic neorealism and constellation analysis of international relations, conceived by Karl-Gottfried Kindermann at the University of Munich in the late 1970s. Although neglected in theoretical reviews of the field, in part because of language barriers, this school is an implicit analytical framework for a large number of practiceoriented studies. Clarity and conciseness of constellation analysis are presented through a small number of elements: system, perceptions, power, interests, norms, and strategies. However, synoptic neorealism goes much beyond the reference framework of structural neorealism in the direction of modern constructivist and critical approaches to international relations, with all advantages and risks that it brings.
\end{abstract}

Keywords: international relations, synopsis, constellation, system, perceptions, power, interests, norms, strategies, interactions, neutrality, multidisciplinarity. 